
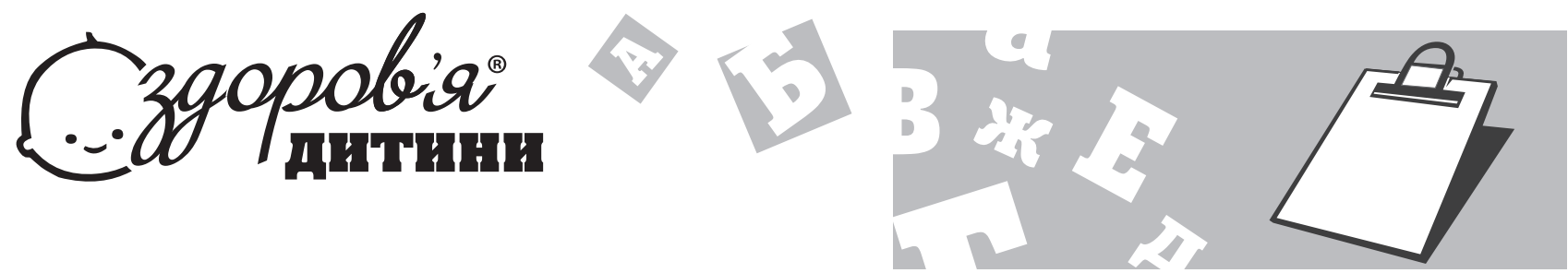

ВипаАок із практики / Case Report

\title{
Clinically suspected myocarditis complicating dengue shock syndrome: a case report and literature review of cardiac complication in dengue-affected pediatric patient
}

\author{
For citation: Zdorov'e Rebenka. 2021;16(4):304-308. doi: 10.22141/2224-0551.16.4.2021.236910
}

\begin{abstract}
We report a case of dengue shock syndrome complicated by clinically suspected acute myocarditis in pediatric patient at a limited-resources hospital in a rural area and review the literature. A 12-year-old boy who experienced dengue shock syndrome developed bradycardia on day $7^{\text {h }}$ of illness. His electrocardiogram during the bradycardia showed sinus bradycardia with a rate of 50 beats per minute. Atropine sulfate and dobutamine, alongside supportive management, were administered. The patient recovered 4 days later. We found a total of seven articles involving pediatric patient with dengue illness and cardiac complications by PubMed search. Clinical manifestations of cardiac involvement in pediatric patient with dengue varied and were mostly transient from tachy-bradyarrhythmia, sinus node dysfunction, low blood pressure, decreased ejection fraction, lower cardiac output, and increased cardiac enzyme. Transient cardiac abnormality can be an important presentation, and physician should have high awareness of cardiac complication in dengue-affected pediatric patients to manage them accordingly.
\end{abstract}

Keywords: dengue; shock; myocarditis; bradycardia; pediatric; case report

\section{Introduction}

Dengue is a viral infection that is transmitted to human by mosquitos of Aedes family. It is endemic in most tropical countries and serious health problems, especially in developing countries of Southeast Asia. Dengue is hyperendemic in Indonesia, where all four serotypes of dengue are found in the region. Among four serotypes of dengue virus (DENV-1, DENV-2, DENV-3, and DENV-4), DENV-3 was the most prevalent in Indonesia [1]. Indonesia typically reports the highest number of cases in the WHO Southeast Asia Region. Prayitno et al. (2017) reported that more than $80 \%$ of children aged 10 years or over have experienced dengue infection at least once in their life [2].

Infection with dengue virus results in a wide range of clinical manifestations from uncomplicated self-limiting dengue fever (DF) to more severe presentation, including dengue hemorrhagic fever (DHF) and dengue shock syndrome (DSS). World Health Organization defines four cardinal features of DHF as: 1) Fever lasting 2-7 days, occasionally biphasic, 2) Hemorrhagic tendency shown by one of the following: positive tourniquet test; ecchymosis or purpura; bleeding from mucosa, gastrointestinal tract, injection sites or other locations; hematemesis or melena, 3) Thrombocytopenia (platelet count $\leq 100 \times 10^{9}$ cells $/ \mathrm{L}$ ), 4) Evidence of plasma leakage owing to increased vascular permeability shown by one of the following: increased hematocrit ( $>20 \%$ above average for age, sex, population); decreased hematocrit after intervention $(>20 \%$ of baseline) [3].

Hadinegoro reported that DSS prevalence in almost all hospitals in Indonesia was $16-40 \%$, with a mortality rate between 5.7 and $50 \%$ [4]. Cardiac complications in DSS are uncommon. Myocarditis is the most frequent form of cardiac complication of dengue reported worldwide. But the clinical manifestations of myocarditis vary considerably from asymptomatic, self-limiting, dysrhythmias,

(c) 2021. The Authors. This is an open access article under the terms of the Creative Commons Attribution 4.0 International License, CC BY, which allows others to freely distribute the published article, with the obligatory reference to the authors of original works and original publication in this journal.

For correspondence: Dita Aulia Rachmi, MD, Departement of Cardiology and Vascular Medicine, Faculty of Medicine, Universitas Airlangga Dr. Soetomo General Hospital, J.I. Mayjen Prof. Dr. Moestopo № 6-8, Surabaya, 60286, Indonesia; fax: + 6231-5031752; e-mail: dita.aulia.rachmi-2019@fk.unair.ac.id; contact phone: + 62 821-2234-0369. Full list of authors information is available at the end of the article. 
to life-threatening myocardial ischemia with cardiogenic shock. Endomyocardial biopsy (EMB) of the myocardium is the golden standard for diagnosing myocarditis, but this method is highly unavailable in Indonesia. This diversity of clinical manifestation and limitation of performing EMB throws a great challenge in diagnosing dengue myocarditis [5].

\section{Case Report}

A 12-year-old boy referred to the emergency department of a limited-resources hospital in a rural area because of 7-day fever associated with black stool, lethargy, hypotension, and bradycardia. He also complained of headache and abdominal pain. His past medical history was unremarkable. He was a developmentally normal child with up-to-date immunization and no history of significant illness or hospitalization. The child was previously treated in another hospital and has received 10 units of thrombocyte concentrate transfusion in the last two days, fluid replacement of ringer lactate infusion, dexamethasone injection, ranitidine injection, and ampicillin injection.

On general physical examination, the child was lethargic but fully aware with a temperature of $36.2^{\circ} \mathrm{C}$, blood pressure was $90 / 60 \mathrm{~mm} \mathrm{Hg}$, heart rate was 65 beats per minute (bpm), respiratory rate was 24 breaths per minute, body weight was $25 \mathrm{~kg}$. Respiratory examination was normal. Cardiovascular examination revealed no audible murmur or other cardiac abnormality. Abdominal pain in epigastric area was found. The rest of his physical examination was unremarkable.

Complete blood count showed leukopenia (white cell count $3.9 \times 10^{-9} / \mathrm{L}$ ) and thrombocytopenia (platelet count $16.000 / \mathrm{mm}^{3}$ ). Hematocrit $46.7 \%$. Electrolyte was within normal limits. Widal test on $4^{\text {th }}$ day of fever (data from previous hospital) was within normal limits. Dengue NS1 antigen and immunoglobulin $\mathrm{M}$ assays were not available. A clinical diagnosis of dengue shock syndrome was made.

The patient was admitted to intensive care unit for close monitoring. He was prescribed fluid replacement of asering infusion, parenteral inotropic agent of dobutamine, metamizole injection to relieve the fever, and ranitidine injection for gastroprotective agent.

Over the next 6 hours, there was an improvement in blood pressure $(112 / 72 \mathrm{~mm} \mathrm{Hg})$, but heart rate was decreased. The patient experienced worsening of bradycardia ranging from 40 to $60 \mathrm{bpm}$. Atropine $0.5 \mathrm{mg}$ was prescribed to treat the bradycardia and repeated every 3 minutes.

Chest X-ray was unremarkable. Electrocardiography (ECG) showed sinus bradycardia (figure 1). Echocardiography 24 hours after admittance was unremarkable and showed normal cardiac function. Evidence of pericarditis or pericardial effusion was not found. A clinically suspected diagnosis of myocarditis caused by dengue virus was made.

Management was focused on the symptomatic treatment of dengue fever with serial monitoring of platelet

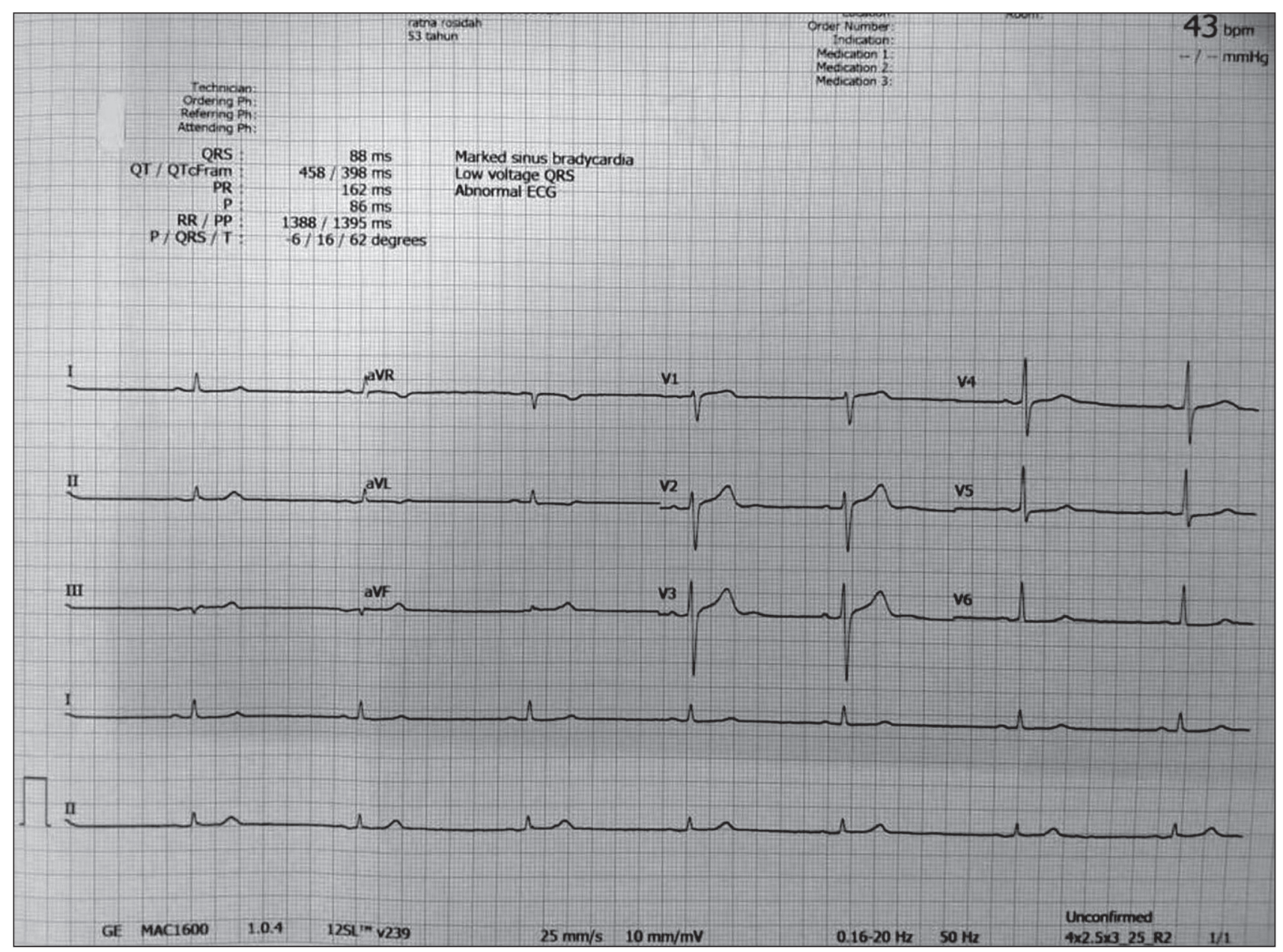

Figure 1. Electrocardiography showed sinus bradycardia 
Table 1. Summary of articles involving pediatric patient with dengue infection and their cardiac manifestation

\begin{tabular}{|c|c|c|c|c|c|}
\hline Article & Study design & $\begin{array}{l}\text { Subject } \\
\text { (person) }\end{array}$ & $\begin{array}{l}\text { Age } \\
\text { (year) }\end{array}$ & $\begin{array}{l}\text { Dengue } \\
\text { classification }\end{array}$ & Cardiac manifestation \\
\hline Kabra et al., 1998 [6] & Clinical study & 54 & $0.5-12$ & DF, DHF, DSS & $\begin{array}{l}\text { Echo: Myocardial dysfunction } \\
\text { (decreased EF) found in all stages of } \\
\text { severity ( } 16.7 \% \text { of total children) }\end{array}$ \\
\hline $\begin{array}{l}\text { Khongphatthanayo- } \\
\text { thin et al., } 2007 \text { [7] }\end{array}$ & Clinical study & 91 & $9-12$ & DF, DHF, DSS & $\begin{array}{l}\text { Echo: Left ventricular disfunction } \\
(\mathrm{EF}<50 \%)\end{array}$ \\
\hline $\begin{array}{l}\text { Gowrishankar et al., } \\
1994 \text { [8] }\end{array}$ & Case report & 1 & 10 & DHF & $\begin{array}{l}\text { ECG: T wave inversion, Echo: LV } \\
\text { Dysfunction, right pleural effusion, } \\
\text { mitral regurgitation } \\
\text { Cardiac enzyme: CPK-MB normal }\end{array}$ \\
\hline $\begin{array}{l}\text { Khongphatthanayo- } \\
\text { thin et al., } 2000 \text { [9] }\end{array}$ & Case report & 2 & 7 & DHF & $\begin{array}{l}\text { ECG: Mobitz type } 1,2 \text { nd degree AV } \\
\text { block, 1st degree AB block, occasional } \\
\text { PVC } \\
\text { Echo: normal } \\
\text { Cardiac enzyme: not stated }\end{array}$ \\
\hline $\begin{array}{l}\text { Promphan et al., } \\
2004 \text { [10] }\end{array}$ & Case report & 1 & 13 & DSS & $\begin{array}{l}\text { ECG: junctional escape rhythm } \\
\text { Echo: left ventricular dysfunction } \\
\text { (EF } 40 \% \text { ) } \\
\text { Cardiac enzyme: elevated CK-MB and } \\
\text { troponin T level }\end{array}$ \\
\hline Shah, 2007 [11] & Case report & 1 & 11 & DSS & $\begin{array}{l}\text { ECG: ND } \\
\text { Echo: left ventricular dilatation, systolic } \\
\text { disfunction } \\
\text { Cardiac enzyme: elevated CPK-MB }\end{array}$ \\
\hline $\begin{array}{l}\text { Aslam et al., } 2016 \\
\text { [12] }\end{array}$ & Case report & 1 & 12 & DF & $\begin{array}{l}\text { ECG: sinus bradycardia ( } 50 \text { bpm) } \\
\text { Echo: decreased EF of } 52 \% \text {, global } \\
\text { hypokinesia } \\
\text { Cardiac enzyme: elevated CK-MB }\end{array}$ \\
\hline
\end{tabular}

Table 2. Diagnostic criteria for clinically suspected myocarditis [5]

\section{Clinical Presentation}

- Acute chest pain, pericarditic, or pseudo-ischemic

- New-onset (days up to 3 months) or worsening of: dyspnea at rest or exercise, and/or fatigue, with or without left and/or right heart failure signs

- Subacute/chronic (3 months) or worsening of: dyspnea at rest or exercise, and/or fatigue, with or without left and/or right heart failure signs

- Palpitation, and/or unexplained arrhythmia symptoms and/or syncope, and/or aborted sudden cardiac death

— Unexplained cardiogenic shock

\section{Diagnostic Criteria}

\section{ECG/Holter/stress test features}

Newly abnormal 12 lead ECG and/or Holter and/or stress testing, any of the following: I to III degree atrioventricular block, or bundle branch block, ST/T wave change (ST elevation or non ST elevation, T wave inversion), sinus arrest, ventricular tachycardia or fibrillation and asystole, atrial fibrillation, reduced R wave height, intraventricular conduction delay (widened QRS complex), abnormal Q waves, low voltage, frequent premature beats, supraventricular tachycardia

II. Myocardiocytolysis markers

Elevated TnT/Tnl

III. Functional and structural abnormalities on cardiac imaging (echo/angio/CMR)

New, otherwise unexplained LV and/or RV structure and function abnormality (including incidental finding in apparently asymptomatic subjects): regional wall motion or global systolic or diastolic function abnormality, with or without ventricular dilatation, with or without increased wall thickness, with or without pericardial effusion, with or without endocavitary thrombi

IV. Tissue characterization by CMR

Edema and/or LGE of classical myocarditic pattern 
counts. On day- 2 of hospital admission, the blood pressure was $122 / 56 \mathrm{mmHg}$, heart rate was $77 \mathrm{bpm}$, respiratory rate was 16 breaths per minute. Temperature was $35.6{ }^{\circ} \mathrm{C}$. The patient was continued on intravenous fluid with no clinical signs of shock.

On day-3, the patient felt so much better and showed no episodes of fever and black stool. Blood pressure, heart rate, respiratory rate, and body temperature were all within normal limit. On day-4, follow-up laboratory data showed increased leucocytes (white cell count $7.8 \times 10^{-9} / \mathrm{L}$ ) and thrombocytes (platelet count $279.000 / \mathrm{mm}^{3}$ ). The patient then was discharged from hospital.

\section{Literature Review}

Literature searching regarding cardiac involvement in dengue infection of pediatric patients was done on PubMed. We included only English-language articles. Total of 7 articles available were acquired and summarized in table 1.

Cardiac manifestation from dengue infection in pediatric patients listed in table 1 were obtained from ECG, Echocardiography, and Cardiac Enzyme examination. Kabra et al. [6] and Khongphatthanayothin et al. [7] clinical study that involved groups of patient showed decreased left ventricular function from echocardiography $(\mathrm{EF}<50 \%)$ in 10 and $36 \%$ pediatric patients with DSS, respectively. ECG abnormalities are common in myocarditis, but it is neither sensitive nor specific [5]. Various ECG abnormalities found in these case reports are $\mathrm{T}$ wave inversion, $1^{\text {st }}$ degree and $2^{\text {nd }}$ degree AV block, junctional escape rhythm, and sinus bradycardia. These ECG abnormalities occurred in all stages of severity of dengue infection [8-12].

\section{Discussion}

The diagnosis of dengue shock syndrome was made because the patient fulfilled four cardinal features of DHF and showed signs of circulatory failure. DSS in pediatric patient require a more meticulous approach because they need very specific volumes for fluid resuscitation and are more susceptible to volume overload stress. In this condition, it is important to increase the index of suspicion for myocarditis, enabling the physician to consider other approaches rather than pursuing vigorous fluid therapy [12].

The presence of unexplained bradycardia in dengue shock syndrome patient raised suspicion of myocarditis (table 2). European Society of Cardiology recommends these first line tests to be done in all patients with clinically suspected myocarditis: 12-lead standard electrocardiography; trans-thoracic echocardiography at presentation; troponins, erythrocyte sedimentation rate, and reactive $C$ protein levels; selective coronary angiography and endomyocardial biopsy [5].

Boon (1967) [13] observed the abnormalities in ECG in as many as $44-75 \%$ patients with viral hemorrhagic fever. Sinus bradycardia and prolonged PR interval are the most common abnormalities. Other abnormalities were ST-segment abnormalities, first degree AV block, premature atrial contraction, and premature ventricular contraction. Aslam, 2016 [12] reported similar cases of DHF in a pediatric patient who experienced sinus bradycardia during recovery phase.
ESC guideline doesn't recommend any specific management for arrhythmia, including sinus bradycardia, and so the proper management needs to be following the bradycardia guideline [5]. Sinus bradycardia in this patient was transient and occurred during the recovery phase DSS. The bradycardia responded well to atropine administration that by the $3^{\text {rd }}$ day of hospitalization, atropine was discontinued.

While the mechanism of sinus bradycardia in dengue patient is not yet well understood, an in vitro research showed that dengue virus could cause an increase of the intracellular calcium in the myocardium. This leads to activation of the intrinsic apoptotic pathway and potentially caused myocarditis in dengue infection [14].

Limitations of this case were laboratory tests to confirm dengue infection, including NS1 antigen test and dengue IgM antibody, were not performed. Second, echocardiography obtained 24 hours after admission, whereas the recommended time is as soon as myocarditis is suspected in a patient. Lastly, EMB is not performed due to unavailability.

\section{Conclusions}

We reported a patient with dengue hemorrhagic fever who fell into dengue shock syndrome condition complicating with suspected myocarditis. Dengue virus can produce atypical manifestations as acute myocarditis leading to cardiogenic shock by a possible direct virus action on cardiomyocytes. Physicians treating dengue patients should be aware of this possible complication.

\section{References}

1. Megawati D, Masyeni S, Yohan B, et al. Dengue in Bali: Clinical characteristics and genetic diversity of circulating dengue viruses. PLoS Negl Trop Dis. 2017 May 22;11(5):e0005483. doi: 10.1371/journal.pntd.0005483.

2. Prayitno A, Taurel AF, Nealon J, et al. Dengue seroprevalence and force of primary infection in a representative population of urban dwelling Indonesian children. PLoS Negl Trop Dis. 2017 Jun 15;11(6):e0005621. doi: 10.1371/journal.pntd.0005621.

3. Hadinegoro $S R$. The revised $W H O$ dengue case classification: does the system need to be modified? Paediatr Int Child Health. 2012 May;32 Suppl 1(s1):33-8. doi: 10.1179/2046904712Z.00000000052.

4. Kan EF, Rampengan T. Factor associated with shock in children with dengue hemorrhagic fever. Paediatrica Indonesiana. 2004;44(5):171-74. doi: 10.14238/pi44.5.2004.171-5.

5. Caforio AL, Pankuweit S, Arbustini E, et al; European Society of Cardiology Working Group on Myocardial and Pericardial Diseases. Current state of knowledge on aetiology, diagnosis, management, and therapy of myocarditis: a position statement of the European Society of Cardiology Working Group on Myocardial and Pericardial Diseases. Eur Heart J. 2013 Sep;34(33):2636-48, 2648a-2648d. doi: 10.1093/eurheartj/eht 210 .

6. Kabra SK, Juneja R, Madhulika, et al. Myocardial dysfunction in children with dengue haemorrhagic fever. Natl Med J India. 1998 Mar-Apr;11(2):59-61.

7. Khongphatthanayothin A, Lertsapcharoen P, Supachokchaiwattana $P$, et al. Myocardial depression in dengue hemorrhagic fever: prevalence and clinical description. Pediatr Crit Care Med. 2007 Nov;8(6):524-9. doi: 10.1097/01.PCC.0000288672.77782.D4. 
8. Gowrishankar K, Rajajee S. Varied manifestations of viral myocarditis. Indian J Pediatr. 1994 Jan-Feb;61(1):75-80. doi: 10.1007/ BF02753563.

9. Khongphatthallayothin A, Chotivitayatarakorn P, Somchit S, Mitprasart A, Sakolsattayadorn S, Thisyakorn C. Morbitz type I second degree AV block during recovery from dengue hemorrhagic fever. Southeast Asian J Trop Med Public Health. 2000 Dec;31(4):642-5.

10. Promphan $W$, Sopontammarak $S$, Pruekprasert P, Kajornwattanakul W, Kongpattanayothin A. Dengue myocarditis. Southeast Asian J Trop Med Public Health. 2004 Sep;35(3):611-3.

11. Shah I. Dengue presenting as viral myocarditis. Dengue Bull. 2007;31:172-3
12. Aslam M, Aleem NA, Zahid MF, Rahman AJ. Unusual Presentation of Dengue Fever: A child with acute myocarditis. Sultan Qaboos Univ Med J. 2016 Feb;16(1):e101-4. doi: 10.18295/squmj.2016.16.01.019.

13. Boon WH, Tan G. Cardiac involvement in haemorrhagic fever. J Singapore Paediatr Soc. 1967 Apr;9(1):28-45.

14. Szalai G, Krishnamurthy R, Hajnóczky G. Apoptosis driven by IP(3)-linked mitochondrial calcium signals. EMBO J. 1999 Nov 15;18(22):6349-61. doi: 10.1093/emboj/18.22.6349.

Received 31.05.2021

Revised 10.06.2021 Accepted 18.06.2021

\section{Information about authors}

Dita Aulia Rachmi, MD, Department of Cardiology and Vascular Medicine, Faculty of Medicine, Universitas Airlangga Dr. Soetomo General Hospital, Surabaya, Indonesia; fax: + 6231-5031752; e-mail: dita.aulia.rachmi-2019@fk.unair.ac.id; contact phone: + 62 821-2234-0369; https://orcid.org/0000-0003-0741-1542.

Drastis Mahardiana, Mardi Waluyo Hospital, Blitar, Indonesia

Eka Prasetya Budi Mulia, Department of Cardiology and Vascular Medicine, Faculty of Medicine, Universitas Airlangga Dr. Soetomo General Hospital, Surabaya, Indonesia; https://orcid.org/0000-00022681-7743.

Agus Subagjo, Department of Cardiology and Vascular Medicine, Faculty of Medicine, Universitas Airlangga Dr. Soetomo General Hospital, Surabaya, Indonesia.

Conflicts of interests. Authors declare the absence of any conflicts of interests and their own financial interest that might be construed to influence the results or interpretation of their manuscript.

Dita Aulia Rachmi', Drastis Mahardiana², Eka Prasetya Budi Mulia', Agus Subagjo1

'Department of Cardiology and Vascular Medicine, Faculty of Medicine, Universitas Airlangga Dr. Soetomo General Hospital,

Surabaya, Indonesia

2Mardi Waluyo Hospital, Blitar, Indonesia

\section{КАінічНО ПіАОЗрЮВаНИЙ МіОКОРАИТ, ЩО УСКАААНЮЄ СИНАРОМ ШОКУ АЕНГе: КАінічНИЙ ВИПААОК та огАяА Аітератури щоАО серцевих УскАаАнень У АИтини із АИхОМанкою Аенге}

Резюме. У статті повідомляється про випадок синдрому шоку денге, ускладненого клінічно підозрюваним гострим міокардитом, у дитини, яка знаходилася в сільській лікарні з обмеженими ресурсами, та наведений огляд літератури. У 12-річного хлопчика, який переніс синдром шоку денге, на 7-й день хвороби розвинулася брадикардія. На електрокардіограмі під час брадикардії зареєстровано синусову брадикардію 50 уд/хв. Поряд із підтримуючим лікуванням вводили сульфат атропіну та добутамін. Пацієнт одужав через 4 дні. За допомогою пошуку в наукометричній базі PubMed ми виявили загалом сім статей, у яких описано лихоманку денге із серцевими ускладненнями в дітей. Клінічні прояви ураження серця в дитини з лихоманкою денге варіювалися та були переважно тимчасовими, від тахі-брадіаритмії, дисфункції синусових вузлів, низького кров'яного тиску, зменшення фракції викиду, зниження серцевого викиду до підвищеного вмісту кардіоферментів. Транзиторні порушення серцевої діяльності можуть бути важливою ознакою, і лікар повинен мати високу настороженість щодо серцевих ускладнень у дітей із лихоманкою денге, щоб проводити відповідне лікування.

Ключові слова: лихоманка денге; шок; міокардит; брадикардія; дитина; клінічний випадок 